\title{
REFORMATION OR REVOLUTION? HERMAN BAVINCK AND HENRI DE LUBAC ON NATURE AND GRACE
}

\author{
Gregory W. PARKER JR. \\ Gordon-Conwell Theological Seminary, South Hamilton
}

\begin{abstract}
Henri de Lubac's treatment of the relationship between nature and grace will be critiqued by Herman Bavinck's 'grace restores nature' theme. In two significant addresses, Bavinck critiqued a Roman Catholic approach to nature and grace. De Lubac's influence upon Roman Catholic thinking addressing nature and grace occurred post-Bavinck and has altered Catholic thinking on the subject. Neo-Calvinist scholar, Wolter Huttinga admits that Bavinck and de Lubac offer similar critiques of Roman Catholicism (Huttinga 2014). The question remains then, do Bavinck's critiques still hold? I propose that Bavinck's account of grace restores nature still makes valid critiques of a post-Vatican II construction of nature and grace. The paper is broken into three sections: (1) an exploration of de Lubac's nature and grace theme, (2) the framework of Bavinck's 'grace restores nature' theme, and (3) a Bavinckian critique of de Lubac's nature and grace theme.
\end{abstract}

KEY WORDS: Herman Bavinck, grace restores nature, Henri de Lubac, nature and grace, Neo-Calvinism, nouvelle théologie

\section{Introduction}

Arvin Vos in his book Aquinas, Calvin, and Contemporary Protestant Thought suggests that the Protestant critique of Catholics on the issue of nature and grace has long been void for they merely critiqued a particular strain of Catholic thought in the 16th and 17th century, that was not really representative of Thomas Aquinas (Vos 1985: 157). Vos' position has been uncritically received by Protestants, such as Paul Helm and John Bolt leading to their denunciation of Herman Bavinck's critique of Catholics on nature and grace (Bolt 2014: 78; Helm 2008). Brian Mattson has noted this uncritical reception and therefore shortsighted critique of Bavinck, which has failed to recognize that 'Roman Catholic theologians themselves articulate Roman Catholic dogma in precisely the dualistic terms Bavinck describes'. Thus,

* GREGORY W. PARKER JR. (MDiv 2017, Gordon-Conwell Theological Seminary) is a ThM student at Gordon-Conwell Theological Seminary, South Hamilton, United States of America. Email: gparker@gordonconwell.edu. 
Mattson responds to Helm's and Vos' critique by stating that 'if later Roman Catholicism, particularly the Counter-Reformation, co-opted Thomas and ran his natural theology in dualistic directions he did not intend, shouldn't the blame for that be laid at the feet of Roman Catholic theologians? Bavinck dealt with Roman Catholicism as it stood, in his time and his place' (Mattson 2013).

While Catholic theologians may shudder at Bavinck's critique, the critique itself has fermented within early 20th-century Catholicism and sprouted in the nouvelle théologie. The nouvelle théologie was a movement of theologians in France that aimed to return to the sources while being ever aware of the development of Christian thought. This movement grew in response to the manual theology that had preceded it, which neglected to read primary theological sources such as Aquinas in favor of reading manuals. The connection between Neo-Calvinists such as Bavinck and nouvelle théologie has been noted before. Neo-Calvinist scholar Jon Stanley has argued, "the neo-Calvinist tradition can indeed find a conversation partner and ally in... French-Catholic nouvelle théologie' (Stanley 2011: 99). It is in the nouvelle théologie that one finds an interpretation of Aquinas that seems to mirror Bavinck's critique, thus vindicating Bavinck and perhaps opening the door for an ecumenical discussion on nature and grace. Merely showing the similarities between the nouvelle théologie and Neo-Calvinists would fail to actually respond to Vos, however, and in turn draw a straight line from Aquinas to Bavinck. This paper, suggests that it would be rather difficult to consider Bavinck and Rome to be easily compatible.

In Bavinck's 1888 address on 'The Catholicity of Christianity and the Church' and 1894 address at Kampen on 'Common Grace' he laments the dualism found in Roman Catholic constructions of nature and grace. Similarly, Jesuit theologian Henri de Lubac, frustrated by the inherent dualism of Roman Catholic nature and grace attempted to integrate the natural and supernatural. De Lubac is often painted as a conflicted thinker, one vacillating between Catholic teaching and his own thoughts striving to breach the divide between Catholicism and modernity (Milbank 2005: 8). However, this may not be altogether helpful de Lubac was traditionally Catholic, but striving to represent the faith in a modern context. Bavinck for a long time was painted in a similar light, but the modern, idealist Bavinck has been put to rest by the introduction of Bavinck's organic outlook, which reflects an archetypal unity-in-diversity rooted in the Triune God enabling him to navigate the divide between orthodoxy and modernity (Eglinton 2010: 67; 2012). De Lubac and Bavinck, in their wrestling with modernity thus at first indeed have much in common in their task to navigate the tension between the two. In this case then, an ecumanical dialogue can certainly be recognized between Neo-Calvinist's and the nouvelle theologie, however distinctives 
that separate them should be recognized with clarity, and not disregarded as insignificant.

One cannot deny that Bavinck engages Catholic thinking. In his Reformed Dogmatics, Thomas Aquinas is one of Bavinck's most often quoted figures, which has led Vos to wrongfully charging him with being a poor Thomist (Bolt 2008: 82, 89; Systsma 2011: 1-56, 27; Vos 2015: 9-36). The issue is not that Bavinck appropriates Thomas, but rather he utilizes an eclectic group of thinkers that would make fitting him into a Thomistic category difficult. Recently, Bavinck scholar Willem J. de Wit wrote that Bavinck might be better described as a 'Reformed Catholic' rather than NeoCalvinist (2014). In his 2011 dissertation, de Wit more fully expands on this theme of Bavinck warmly engaging Catholic thinking (46-51). However, other Bavinck scholars have sought to balance these studies showing Bavinck as more critical in his interaction with Catholic thinkers and in particular that he appropriated too many different theologians to be considered an endorser of any 'ism' whether Thom'ism' or ideal'ism' (Mattson 2012; Eglinton 2012; Brock and Sutanto 2017).

In other words, Bavinck distinguishes himself from the Catholic sources he engages. One scholar, Gray Sutanto, has argued that part of Bavinck's theological genius is his ability to diachronically resource particular theological thinkers, while avoiding systematic endorsement through synchronic re-appropriation via his organic motif (Sutanto 2016). This builds the case for Bavinck as having similar theological goals as that of the nouvelle théologie, while remaining within the boundaries of his Reformed confessional methodology, theology, and context.

It is difficult to discern de Lubac's exact engagement with Protestant thinking. He does occasionally make assertions about Protestantism's limitations, though these often seem to be veiled critiques of Karl Barth (de Lubac 1986: 158; 1993: 70). His more direct interactions with Protestantism come from his critiques of Protestant ecclesiologies in Catholicism, The Splendor of the Church, and More Paradoxes in which he critiques them as 'human inventions' (de Lubac 2002: 123). It is John Calvin, however, and not Barth, whom de Lubac interacts with the most (de Lubac 1980: 122). It does appear that de Lubac was at least aware of Protestant critiques of nature and grace and was open to ecumenical dialogue (de Lubac 1980: 35, 96).

The two theologians thus present an interesting opportunity to reflect on nature and grace. Particularly, do Bavinck's critiques still hold water after de Lubac's influence on Catholic thinking? In these two significant addresses, Bavinck critiqued a Roman Catholic approach to nature and grace. De Lubac's influence upon Roman Catholic thinking addressing nature and grace occurred post-Bavinck and has altered Catholic thinking on the subject. David Grummet suggests that de Lubac is less representative of Tho- 
mism as he is of Augustinianism, which Vos would disagree with (Vos 1985: 153; Grummet 2015: 138). Interestingly, what this paper is more representative of then is the continued difference between Protestants and Catholics despite the development of Catholic thought in Vatican II, which reacted against earlier interpretations of Aquinas. Rather than examining all of Catholic thinking since de Lubac, we will proceed by inspecting de Lubac's own work A Brief Catechism of Nature and Grace. Even here, much ink has been profitably spilt and to trace every interpreter is nearly impossible so in following de Lubac's own title the description will be brief. This will be followed by Bavinck's own nature and grace theme, and then Bavinck's critiques of Rome's nature and grace scheme will reveal that Bavinck's critiques are still warranted.

\section{Nature and Grace in de Lubac}

'Like a mouse stuck in tar' is how de Lubac describes the elusiveness of defining a word like nature, admitting its theological definition can only be understood in light of its relationship to its counterpart 'supernatural' (de Lubac 2008; 5, 12-13). De Lubac attempted to create space for both nature and supernatural to have their own ontology, while also realizing their deep interconnectedness: what John Milbank calls de Lubac's 'non-ontology' and what de Lubac describes as the 'organic link' between the supernatural and the natural (de Lubac 1988: 313). This non-ontology sets grace and nature paradoxically on two different, equal trajectories. The supernatural is always manifest in the natural, and the natural always points beyond itself to the supernatural. De Lubac worked this schema out over his ecclesiological and sacramental works.

Nature and grace for de Lubac can be elucidated in three points. Firstly, de Lubac believed that humans were created for communion with God and therefore had a natural inclination to desire God. Secondly, nature and grace are unique in that they are both a gift from God, however, there is the necessity to distinguish them. Thirdly, the natural desire for the supernatural is incomplete without grace. These three features of de Lubac's nature and grace will be explored below.

Firstly, the desire for the supernatural is an intrinsic desire for humanity. De Lubac's thought shines clearer against the background of extrinsicism in nature and grace. In Catholic nature and grace thought, extrinsicism is the belief that there is a clear distinction between nature and grace, for the purpose of preserving the gracious act of God. In extrinsicism, the supernatural acts outside of nature and is alien to human nature. Intrinsicism, on the other hand, emphasizes that nature and grace are intertwined, such that there is no such thing as a natural end. Human nature is oriented to- 
wards the supernatural. Since human beings desire a supernatural end they do not have a 'pure nature'. It is already directed towards the supernatural.

He does admit however, that it is possible that 'a universe might have existed in which man, though without necessarily excluding any other desire, would have his rational ambitions limited to some lower, purely human beatitude' (de Lubac 1998: 54). In other words, 'pure nature' might be plausible in a possible world. De Lubac posits however that this is unsustainable if man is naturally geared towards a supernatural end. De Lubac seems to indicate that 'pure nature' is nothing more than a tool constructed to enable theological reasoning (Grummett 2015: 131-133).

When de Lubac defines supernatural in his Brief Catechism he does so by defining it as intrinsic. He specifically denies that it is something superadded to nature, but rather their relationship is one of 'synergy' (de Lubac 1980: 26, 122). The two are not 'distinct' natures like 'juxtaposed realities', but rather 'the supernatural... is that divine element which man's efforts cannot reach... penetrating him in order to divinize him, and thus becoming as it were an attribute of the "new man" (de Lubac 1980: 41). He believes there is a natural desire for God in humans. However, this cannot be separated from the fact that de Lubac believes that it is in exactly this way that grace is bestowed. The ultimate end of humanity's natural order is supernatural, and is so by grace. Humanity, therefore, has an intrinsic desire for God, but it is a desire that God has graciously given it. This is made clearer by de Lubac's second distinctive.

Secondly, nature and grace are in 'intimate union', while also being of 'spiritual otherness and of infinite distance' (de Lubac 1980: 49). Nature and the supernatural have a unique relationship of being at once tightly knit and in 'relationship of opposition' (de Lubac 1980: 49). They are distinct in that one is the gracious act of creation (nature) and the other the gracious act of divinization (de Lubac 1980: 50). The gift of nature and grace is a twofold gift from God. De Lubac attempts to reveal that his position is compatible with the fundamental truth of God's freedom. He affirms the gratuity of the original creation but distinguishes 'the fact of creation of a spiritual being' from the 'supernatural finality imprinted upon that being's nature' and both of these... are to be distinguished in order to avoid hindering 'God's utter independence' (Leithart 2011: 108). De Lubac writes of 'the first gift of creation and the second wholly distinct, wholly supereminent gift, the ontological call to deification which will make of man, if he responds to it, a 'new creature' (de Lubac 1998: 76). The supernatural, therefore, is an agent 'a ferment, a soul, not a complete organism; it comes to transform "nature" (de Lubac 1980: 49). Grace is therefore the gracious cause of deifying grace. It acts upon nature, not from the outside, but from within, for nature itself is a gift of grace. 
Nature exists in an Aristotelian sense for de Lubac: "nature is a principle, or cause of being moved and of being at rest in that to which it belongs primarily, in virtue of itself and not accidently' (Aristotle 1992: 192b 21-23). Nature is a not a thing in itself, but rather is a created cause that exists within things. Therefore, both nature and grace are gift of God and thus gratuitous. For de Lubac the difference between the two is the purpose for which each one was gifted. According to de Lubac, God has created humans with a natural desire for the beatific vision. However, this can only be attained by grace. Nature is incapable without grace of attaining to its supernatural end. Importantly, this desire latent in humans is an indicator that the natural order is created for grace.

The third defining characteristic of de Lubac's nature and grace theme, therefore, is that the natural desire for the supernatural is incomplete without grace. God has given humanity in his natural desire, prior to grace, a desire for that which is beyond nature. De Lubac roots this natural desire for the supernatural in the Imago Dei. In other words, human beings are created in the image of God with the ability, or readiness, to receive grace. Therefore, in his very nature humanity has inscribed, prior to grace, a desire for the beatific vision, which is fulfilled by sheer grace. 'Human nature, in each of us, is always both created and sinful; it is always in fact the sinful human who is gratuitously called to conversion, to divine life; and it is always in fact this divine life which is gratuitously given him along with the pardon for his sins' (de Lubac 1980: 168). In summary, both are a gratuitous gift, but one, grace, works through the natural to bring it to the telos for which it was created. The deepest desires are innately directed towards God but require grace to complete the mission. In de Lubac's thought, the natural desire cannot reach its ultimate end without grace.

\section{Nature and Grace in Bavinck}

Jan Veenhof's dissertation Revelatie en Inspiratie asserts four characteristics of Bavinck's nature and grace theme (Wolters 2006: 11-31). Firstly, that it is Trinitarian, which should come as no surprise that Bavinck's other major theme, 'the organic motif,' dovetails with nature and grace. Secondly, sin is an 'accidental' component of created life 'in the philosophical sense of not belonging to the essence or substance of things' (Wolters 2006: 20). Therefore, human nature itself is not changed in redemption, but rather sin is removed from it:

Sin is not a substance, but a quality; not materia, but forma; it is not the essence of things, but rather adheres to the essence of things; it is a privatio, though a privatio actuosa, and to that extent contingent, an alien intruder like death. It can therefore be isolated from the essence and removed from it. The world is and 
remains susceptible to purification and deliverance. Its essence can be saved, and its original state can return (Bavinck 1989: 60).

Thirdly, grace restores nature by reformation not revolution (Wolters 2006: 21). Revolution would entail a change of essence, or a change in nature, while reformation entails the removal of sin from that essence. Therefore, instead of a transformation or elevation of human nature the removal of sin acts as reformation not revolution.

Fourthly, Veenhof argues that Bavinck's grace is restoration, not reprinstation. A distinction between the return to the garden, reprinstation, and the 'Christ gives more than sin took away; grace did much more abound' in restoration (Bavinck 1989: 59). In this view of Bavinck's 'grace restores nature' theme takes us beyond the garden to our destiny. This can be understood clearer through Bavinck's covenant theology framework. 'Bavinck's covenant theology provides the architecture for his thesis that grace restores and perfects nature' (Mattson 2012: 234). Grace and nature are not pitted against one another, but rather an organic fulfillment of God's purposes in and for creation. In its most basic form, then, the formulation that grace restores nature flows from 'Bavinck's Trinitarian commitment' to the belief 'that the world God created, now fallen, is restored by the work of the Son and perfected by the re-creating power of the Holy Spirit' (Mattson 2012: 5). Therefore, the natural order is not elevated, but restored. 'Christianity does not introduce a single substantial foreign element into creation. It creates no new cosmos but rather makes the cosmos new. It restores what was corrupted by sin. It atones the guilty and cures what is sick; the wounded it heals' (Bavinck 1989: 61). Therefore, to understand how grace restores and perfects nature in Bavinck's work we must briefly explore his covenant theology.

The covenant of works is a familiar doctrine to Reformed Theology, in Bavinck's explanation he organically links creation with a particular eschatology. Bavinck indicates a latent telos within the garden when he writes, 'paradise was not heaven' (Bavinck 2004: 573). In other words, 'grace does not grant anything beyond what Adam, if he had remained standing, would have acquired in the way of obedience' (Bavinck 2006: 577). However, Adam failed in his eschatological quest, and thus we turn to the covenant of grace. Bavinck is keen to not separate teleologically the covenant of grace from the covenant of works: 'the covenant of grace differs from the covenant of works in the road, not in its final destination' (2006: 577). However, in the covenant of grace the telos of creation is met. Therefore, the covenant of grace perfects the eschatological destiny set forth for humanity in the covenant of redemption.

In summary, the 'grace restores nature theme' in Bavinck is an act of the Trinity cemented in the covenant of redemption, in which the Father, Son, 
and Spirit restore creation to the telos for which it was created. Prior to the fall human nature had an eschatological destination. When humanity sinned, this telos is interrupted, and humanity is then incapable of reaching his destiny. Grace removes sin and grants humanity his destiny through Christ. In other words, the covenant of works and the covenant of grace had the same telos, but the covenant of grace brings humanity beyond the garden to his true destiny.

\section{A Bavinckian Critique of De Lubac}

Separated by time, culture, and ecclesiastical structures, Bavinck and de Lubac both wield the theological theme of nature and grace, both grapple with the shift in society towards modernity, and both land on opposite sides of the Protestant-Catholic divide. Jon Stanley lists two similarities between Bavinck and nouvelle theologie on issues of nature and grace. First, both are critical of dualistic construals of nature and grace. Second, both make a distinction between 'creational grace' and redemptive grace' (Stanley 2011: 100). However, can one really say that the nouvelle theologie and NeoCalvinists are two-sides of the same coin? In his 1888 address on 'The Catholicity of Christianity and the Church' and his 1894 address on 'Common Grace' Bavinck makes four critiques of the Roman Catholic construction of nature and grace which will be addressed in turn: (1) The natural and supernatural are always at odds in Rome's construction. (2) Roman Catholic understandings of nature / grace create a vacuum in which natural religion can exist. (3) Rome fails to understand sins pervasiveness and thus perverts its ethics. (4) Rome makes the image of God an accidental property of humanity rather than essential.

\section{The Natural and Supernatural Are Always at Odds in Rome's Construction}

De Lubac laments the dualism that exists in Thomistic thought on the natural and supernatural. Yet, he does not construct nature and grace as moving in the same hypothetical direction. Nature and grace may belong to the same 'non-ontology' for de Lubac, but they remain opposed to one another.

The distinction between nature and grace in this instance is much more radical than in the case of the general differentiation between nature and the supernatural. It no longer suffices to say that the supernatural is something altogether different from a prolongation or a fulfillment of nature, something entirely different from the indispensable help nature needs to attain its profoundest desires. Between sinful human nature and divine grace, we have not only a dissimilarity, a heterogeneity between two orders of being, an infinite distance that man alone cannot bridge. There is an antagonism, violent conflict ('natura filii irae' says St. Paul). Between grace and sin the struggle is irreconcilable. Consequently, the call to grace is no longer 
an invitation to a simple 'elevation', not even a 'transforming' one (to use the traditional words); in a more radical fashion it is a summons to a 'total upheaval', to a 'conversion' (of the 'heart', i. e., of all one's being) (de Lubac 1980: 119).

There is much here with which Bavinck would agree. He would concur with the language of grace and $\sin$, for that is where he perceives the true antithesis to be. 'The Reformation antithesis between sin and grace has more or less made way for the Catholic antithesis between the natural and the supernatural' (Bavinck 2006: 568). He would agree that grace cannot be viewed as something that creates an 'elevation' in nature. Where Bavinck and de Lubac disagree, and thus Bavinck's critique carries through is in the continued framework of 'two orders of being'. One must recognize that de Lubac is attempting to move beyond this and perhaps even towards the antithesis of grace and sin, however it is this very description that de Lubac imports into 'nature' and 'supernatural' (de Lubac 1980: 119-120). De Lubac maintains the two orders and therefore maintains the dualism that exists within the system. It is not sin that is removed from humanity for de Lubac, but her entire nature that is revolutionized.

The antagonism that exists between grace and sin for de Lubac is the difference between the natural and the supernatural. Bavinck writes, critiquing Rome, that 'the natural is not that which is sinful but that which by its very nature is incapable of reaching the supernatural' (Bavinck 1992: 229). Therefore, grace merely supplements nature through the transformation of nature (de Lubac 1980: 81). For Bavinck, the antithesis between grace and $\sin$ is not one of nature, for sin is metaphysically an accidental property. Sin can be removed from humanity (Bavinck 1989: 60). Peter Leithart makes a similar argument against De Lubac's construction stating that, if nature stands in an oppositional relation with the supernatural, then they must be external to one another, and how is this externality distinguishable from extrinsicism?' In the end, Leithart concludes de Lubac fails to truly eliminate the dualism (Leithart 2014). We may admit that Bavinck and de Lubac's concerns remain the same in wanting to eliminate the inherent dualism, however we must conclude that de Lubac's construction does not alleviate him from receiving this critique. For de Lubac the natural and the supernatural are still at odds.

Rome's Understanding of Nature / Grace Creates a Vacuum in Which Natural Religion Can Then Exist

Echeverria, a Catholic theologian, who frequently engages Catholic and Protestant thinking would demur with Bavinck's critique. Echeverria suggests that Bavinck is 'simply mistaken' in his interpretation of Catholics (Echeverria 2010: 113). In this article, Echeverria strives to dismantle Bavinck's charge of Catholic rationalism aimed at Aquinas and Vatican I. 
Since this paper deals primarily with Vatican II and Henri de Lubac, and is not aimed at addressing all of Protestant and Catholic critiques related to nature and grace we will engage it momentarily, and only because Echeverria attacks Bavinck specifically. Echeverria effectively ignores Bavinck's critiques of Rome's construction, so rather than re-introducing Bavinck we will use the mirror of de Lubac and his critiques of Catholic thinking to reveal Bavinck's critiques were not simply adrift.

Bavinck's critique is rooted in his understanding of Rome's doctrine of creation and the fall. First, humanity was created as a rational and moral creature. Second, the divine image was added to humanity. This was then lost at the fall through sin. Through the loss of the divine image humans revert back to the first act of creation humanity as a moral, rational, sensuous being. Apart from the effects of society humanity is therefore good and can pursue 'a good and pure religion' (Bavinck 1989: 45-46). De Lubac constructs his image of God differently, making it an essential property to the nature of humans. This partially mitigates Bavinck's critique by removing the image of God as accidental. As a byproduct of this theological move de Lubac eliminates the natural end of humanity as a possibility, for de Lubac viewed 'pure nature's' autonomous status as being fraught with danger.

However, Bavinck's critique is not mitigated fully. First, we must be reminded that because of Humani Generis Catholics leave the door open for a protestant critique on this point (Milbank 2005: 42). Therefore, while de Lubac removes 'pure nature', he retains a natural theology as part of the larger Catholic stream of thought. Second, this does not mitigate Bavinck's critique of Aquinas or the contemporary interpretations of him, but rather it is here that de Lubac reveals his Augustinian rather than Thomistic cards and we must conclude that Bavinck's critique still holds, even if it loosely applies to de Lubac. Echeverria posits that the Catholic tradition as a whole does not believe in natural theology, as Bavinck has critiqued. What Echeverria really means is that the tradition that he holds to and believes to be the correct interpretation of Aquinas does not read him in this way. This is precisely why de Lubac desired to remove the purely natural end, for he wanted to remove the opportunity for secular humanism to flourish under Catholicism (de Lubac 2000: 112).

\section{Bavinck Critiques Rome as Failing to Understand Sins Pervasiveness and} thus Perverts Its Ethics

The Reformation itself was for Bavinck one that involved ethics. He writes, 'the Reformation was a reform of life and morals... They created new ethics' (Bavinck 1880: 3). ['De Reformatie was eene Hervorming des levens en der zeden... Zij schiep eene nieuwe Ethiek'. My own translation.] Reformed ethics rely on humanity's inability to do good apart from common grace 
and regenerative faith, for 'grace does not remain outside or above or beside nature but rather permeates and wholly renews it' (1989: 59). On the other hand, classical Catholic ethics hinge on the supernatural transcending the natural, which Bavinck suggests creates two kinds of children: those who conform to the world, and those who flee it (1989: 48). Bavinck's critique of de Lubac would be that he has not accounted truly for the effect of sin and in turn has an inadequate appreciation of common grace. Interestingly, de Lubac seems aware of these two children: 'The Christian must be on his guard not to fall into the delusion of a "super-naturalism" which would make him neglect his truly human tasks, i.e., in the terms of our distinction his "natural" tasks; or, on the contrary, allow him to become so absorbed by them as to take them for his ultimate end, and by that very fact accomplish them badly' (de Lubac 1980: 81).

A multiplicity of scholars have noted similarly that de Lubac tethered the natural to the supernatural too closely resulting in a distorted moral theology (Bushlack 2015: 87). Thomas Bushlack notes that de Lubac's 'philosophical oversight' in failing to make a distinction on humanity's pre- and post-fall nature leads de Lubac down a difficult path (Bushlack 2015: 92). It is this exact distinction that a Reformed covenantal framework like Bavinck's provides. How does this distort de Lubac's ethics? Positively, de Lubac saw the danger in a purely humanist ethic (Milbank 2005: 22). However, with a distorted understanding of sin there is latent hazard within de Lubac's ethic to perceive ethics as having salvific merit. Furthermore, the failure to truly eliminate the inherent dualism and the extrinsicism hangover it leaves de Lubac with creates space for a further critique. Ethics remain for de Lubac deontological.

Peter Leithart offers a further critique in arguing that for the nouvelle théologie humanities distance from God is their createdness and not their fallenness (Leithart 2014). However, for Bavinck that is not where the problem lies. It is not that God is external to creation, but rather that the whole realm of creation has become alienated from God through sin. This critique of Bavinck's therefore remains intact and in connection with the previous critique opens the door for the latent natural religion present in de Lubac's thinking. If sin has not radically altered one's rational powers, one must conclude that de Lubac still leaves room for natural religion.

One must engage Echeverria here again, for he posits that Bavinck's, and then later James K. A. Smith's critique of Catholics on this point is mistaken. Both Bavinck and Smith attribute the 'wounding of nature', a phrase Aquinas uses to talk about sin, to indicate in Echeverria's words, 'merely the loss of a supernatural addition, leaving the realm of nature intact, including the intellect, if that means unaffected by sin' (Echeverria 2010: 96). Rather than appealing to Aquinas, Echeverria utilizes an extended quote by 
Etienne Gilson. Here Echeverria reveals himself as one working within his own Thomistic tradition. Where Echeverria strives to draw Catholics and Protestants closer together, de Lubac highlights that the difference remains. De Lubac admits, 'our sinful nature is not completely corrupted by sin' as Protestants like Luther and Calvin claim on the nature of $\sin$ (1980: 122).

\section{Rome Makes the Image of God an Accidental Property of Humanity Rather}

Than Essential

De Lubac varies from pre-Vatican II Roman Catholic thought on this issue. He argues that the image of God is a necessary property of humans when he writes, 'was it not shown to them in Genesis, where it was taught that God made humans in his own image? For the divine image does not differ from one individual to another: in all it is the same image' (1980: 29). Elsewhere he states, 'in these conditions, all infidelity to the divine image that man bears in him, every breach with God, is at the same time a disruption of human unity. It cannot eliminate the natural unity of the human race, the image of God, tarnished though it may be, is indestructible' (1988: 33). One of the main arguments he asserted was that neither the early church Fathers nor medieval scholastics truly held to a 'pure nature' doctrine. Therefore, natural humanity did not have a natural end but was always oriented towards a supernatural end. He also does not continue in the tradition that argues for the image of God as being lost in Adam's sin: 'in these conditions, all infidelity to the divine image that man bears in him, every breach with God, is at the same time a disruption of human unity. It cannot eliminate the natural unity of the human race, the image of God, tarnished though it may be, is indestructible' (de Lubac 1980: 33). Therefore, the image of God is not an accidental property and Bavinck's critique no longer is applicable on this point.

\section{A Bavinckian Critique: Conclusion}

Is it the case that Bavinck and the nouvelle théologie are cut from the same cloth? We must answer in the negative. Bavinck's four-pronged critique of Roman Catholic teachings on nature and grace draws out clear distinctions that remain between Protestants and Catholics after Vatican II. While there are certainly similarities between Bavinck and de Lubac's critiques of Rome, the parallels are only skin deep as there is still significant difference between their nature and grace theme. Vanhoozer contrasts the problem vividly when he says, "The Gospel is the good news that men and women are adopted as children of God, not because human nature has by grace been "elevated", but because human sinners (persons) have been forgiven' (Vanhoozer 2016: 49). One must recognize in de Lubac's own critiques of Rome, that he too is challenging the Thomistic tradition that Echeverria 
and others claims is non-existent. Therefore, we must not only consider Bavinck's critiques vindicated against Vatican II constructions, but also recognize that Bavinck was not 'simply mistaken' in his critiques of Vatican I constructions in his day.

A few problem areas remain. Firstly, grace and nature remain oppositional for de Lubac. So although de Lubac denounces that there is dualistic 'superadditum' that elevates nature, nature is still transformed. For De Lubac, therefore, nature and grace is one of revolution. For Bavinck nature is reformed at the loss of sin. Secondly, de Lubac's ethics remain deontological due to the inherent dualism that remains within the system. One must suggest then with Mattson that the uncritical reception of Aquinas by Protestants, and in this case especially in Post-Vatican II constructions is unwarranted. While Catholic theologians and some Protestants may continue to shudder at Bavinck's critques it ultimately is unhelpful to gloss over the differences between the two. Perhaps Bavinck's covenantal framework would provide de Lubac the coherence that his system desires, for 'all of Scripture preaches the unity of God, that is, the unity of God of nature and of the God of grace, and therefore it cannot dualistically separate creation and recreation, for it always binds them organically and harmoniously together' (Bavinck 2017:105).

\section{Bibliography}

Aristotle (1992) The Complete Works of Aristotle, book II, chapter 1. Barnes J (ed). Clayton, GA: InteLex Corporation.

Bavinck H (1992) The Catholicity of Christianity and The Church. Calvin Theological Journal 27(1): 220-251.

Bavinck H (1989) Common Grace. Leeuwen R (trans). Calvin Theological Journal 24(1): 35-65.

Bavinck H (1880) De Ethiek van Ulrich Zwingli. Kampen: Zalsman.

Bavinck H (2003) Reformed Dogmatics, volume 1: Prolegomena. Bolt J (ed), Vriend J (trans). Grand Rapids, MI: Baker Academic.

Bavinck H (2004) Reformed Dogmatics, volume 2: God and Creation. Bolt J (ed), Vriend J (trans). Grand Rapids, MI: Baker Academic.

Bavinck H (2006) Reformed Dogmatics, volume 3: Sin and Salvation in Christ. Bolt J (ed), Vriend J (trans). Grand Rapids, MI: Baker Academic.

Bavinck H (2008) Reformed Dogmatics, volume 4: Holy Spirit, Church, and New Creation. Bolt J (ed), Vriend J (trans). Grand Rapids, MI: Baker Academic.

Bavinck H (2017) Modernisme en Orthodoxie: a Translation. Pass B (trans). The Bavinck Review 7(*): 63-114. 
Bolt J (2008) 'Sola Scriptura as an Evangelical Theological Method?' in Reforming or Conforming? Post-Conservative Evangelicals and the Emerging Church. Johnson G \& Gleason R (eds). Wheaton, IL: Crossway, pp. 62-92.

Bolt J (2014) An Adventure in Ecumenicity: A Review Essay of Berkouwer and Catholicism by Eduardo Echeverria. The Bavinck Review 5(*): 76-89.

Brock C and Sutanto NG (Forthcoming 2017) Herman Bavinck's Reformed Eclecticism: On Catholicity, Consciousness and Theological Epistemology. Scottish Journal of Theology.

Bushlack T (2015) The Return of Neo-Scholasticism? Recent Criticisms of Henri de Lubac on Nature and Grace and Their Significance for Moral Theology, Politics, and Law. Journal of the Society of Christian Ethics 35(2): 83-100.

De Lubac H (1993) At the Service of the Church: Henri de Lubac Reflects on the Circumstances that Occasioned His Writings. Englund AE (trans). San Francisco, CA: Ignatius Press.

De Lubac H (1980) A Brief Catechesis on Nature and Grace. San Francisco, CA: Ignatius Press.

De Lubac H (1988) Catholicism: Christ and the Common Destiny of Man. San Francisco, CA: Ignatius Press.

De Lubac H (1986) The Christian Faith: An Essay on the Structure of the Apostles' Creed. Arnandez R, FSC (trans). San Francisco, CA: Ignatius Press.

De Lubac H (2000) Augustinianism and Modern Theology. New York, NY: Crossroad Publishing Company.

De Lubac H (2002) More Paradoxes. Englund AE (trans). San Francisco, CA: Ignatius Press.

De Lubac H (1998) The Mystery of the Supernatural. Sheed R (trans). New York, NY: Crossroad.

De Wit JW (2014) Neo-Calvinism, Roman Catholicism, and Reformed Catholicism. willemjdewit.com/2014/02/14/neo-calvinism-roman-catholicism-and-reformed-catholicism/

De Wit JW (2011) On the Way to the Living God: A Cathartic Reading of Herman Bavinck and An Invitation to Overcome the Plausibility Crisis of Christianity. Amsterdam: VU University Press.

Echeverria E (2010) The Reformed Objection to Natural Theology: A Catholic Response to Herman Bavinck. Calvin Theological Journal 45(1): 87116.

Eglinton JP (2010) Bavinck's Organic Motif: Questions Seeking Answers. Calvin Theological Journal 45(1): 51-71.

Eglinton JP (2012) Trinity and Organism: Towards A New Reading of Herman Bavinck's Organic Motif. London: T\&T Clark.

Gleason R (2010) Herman Bavinck: Pastor, Churchman, Statesman, and Theologian. Philipsburg, NJ: P\&R Publishing. 
Grummett D (2015) De Lubac, Grace, and The Pure Nature Debate. Modern Theology 31(1): 123-146.

Helm P (2008) Natural Law and Common Grace. Helm's Deep. Paulhelmsdeep.blogspot.com/2008/11/natural-law-and-common-grace.html.

Huttinga W (2014) Herman Bavinck and the Catholic Tradition of Participation. academia.edu/12408557/Herman_Bavinck_and_the_Catholic_Tradition_of_Participation.

Leithart PJ (2011) Athanasius: Foundations of Theological Exegesis and Christian Spirituality. Grand Rapids, MI: Baker Academic.

Leithart PJ (2014) Residual Extrinsicism. First Things. firstthings.com/blogs/leithart/2014/05/residual-extrinicism.

Mattson BG (2012) Restored to Our Destiny: Eschatology E The Image of God in Herman Bavinck's Reformed Dogmatics. Leiden: Brill.

Mattson BG (2013) A Soft Spot for Paganism? Herman Bavinck and 'Insider' Movements. The Bavinck Review 4(*): 32-43.

Milbank J (2005) The Suspended Middle: Henri de Lubac and the Debate Concerning the Supernatural. Grand Rapids, MI: Eerdmans Publishing Company.

Stanley J (2011) Restoration and Renewal. The Kuyper Center Review, Volume 2: Revelation and Common Grace. Bowlin J (ed). Grand Rapids, MI: William B. Eerdmans Publishing Company.

Sutanto NG (2016) 'Retrieval and Re-interpretation: Herman Bavinck's Eclectic Catholicity and the Organic Motif in His Theological Epistemology.' AAR Annual Meeting: Reformed Theology Group. November 22, 2016.

Sytsma D (2011) Herman Bavinck's Thomistic Epistemology: The Argument and Sources of his Principia of Science. Five Studies in the Thought of Herman Bavinck, A Creator of Modern Dutch Theology. Bolt J (ed). Lewiston, NY: Edwin Mellen, pp. 1-56.

Vanhoozer K (2016) Biblical Authority after Babel. Retrieving the Solas in the Spirit of Mere Protestant Christianity. Grand Rapids, MI: Brazos Press.

Veenhof J (1968) Revelatie en Inspiratie. Amsterdam, 345-365. Wolters, AM (trans). 'Nature and Grace in Bavinck', Pro Rege, pp. 11-31.

Vos A (1985) Aquinas, Calvin, and Contemporary Protestant Thought. A Critique of Protestant Views on the Thought of Thomas Aquinas. Grand Rapids, MI: William B. Eerdmans Publishing Company.

Vos A (2015) Knowledge according to Bavinck and Aquinas The Bavinck Review $6(*): 9-36$. 